\title{
Evolution of National Identity in Montenegro
}

\author{
Msc. Shkelzen Imeri \\ Diplomat, Ministry of Foreign Affairs
}

\section{Doi:10.5901/ajis.2016.v5n3p141}

\begin{abstract}
While the current political atmosphere can be attributed to events over the past six monthsThe origin of identity in Montenegro and the desire for independence, lie deep in history. It represents the continuation of the movement of the inner centrifugal forces and simultaneously instigated from outside. These have existed since the old Yugoslavia, while these are deeply ingrained in the political institutions for the creation of identity in Montenegro.It is There are still internal public debates regarding the Montenegrin nationality and citizenship of this population. The issue of identity in Montenegro is closely related to the history and development of the country. The most controversial issue is related to the lack of historical continuity and is mainly argued in contesting its existence as an independent state or as a nation-state. The data show that there has been a movement of population with different national identities in the border regions of Montenegro. The issue of identity and crossing the border areas, especially when it comes to those places where borders were often the subject of discussion for change and population were found in situations where national identity became increasingly fluid. The methodology of this study is based on indicators of the census in Montenegro in 1948, where the number of people who were registered as Montenegrins in Montenegro (declared Montenegrin ethnicity) was 90.67\%; later on, it has been dropping to $67.15 \%$ in 1971 and to $61.86 \%$ in 1991; the number of citizens who declared themselves Montenegrin dropped sharply to $44.98 \%$ in 2011. Change of the declaration of Montenegrin ethnicity has been influenced by various factors and complex internal and external, including economic development, freedom of expression, increase of cultural level, as well as the interference of external factors (in 1948, break up relations with the Soviet Union). Determination of the elements that have contributed to the declaration of Montenegrin ethnicity is of interest herein.
\end{abstract}

Keywords: Identity, census, nationality (ethnicity), factor, interests, independence, economic development.

\section{Introduction}

Montenegro has been an internationally recognized independent country in 1878 at the Congress of Berlin until it has been annexed to the Kingdom of Serbs, Croats and Slovenes in 1919 when "the Montenegrin people did not have an opportunity to exercise their right to self-determination according to international norms". The term "annexed" is a term of dispute when discussing Montenegrin nationhood and the infamous Podgorica Assembly of 1919 that led to the loss of independence is being reiterated even today in public discourse among elites both in Serbia and in Montenegro (Pavlović, 2008). Montenegro has a discontinued tradition regarding the independence, which lies before, during and after the creation of Yugoslavia, where Serbia and Montenegro had a common border. This was the result of the First Balkan War in 1912. Montenegro has a tradition of precarious independence stretching back long before thBy this time, pressures and different movements existed within the Montenegrin society, between those who seek union with Serbia, and those who wish to remain independent. According to historian John R. Lampe: "The loss of identity through union with Serbia on the grounds that it is a small and isolated country, or is created the third alternative, under which being part of the Yugoslav state, it would be attractive for the majority of Montenegrins, especially after two world wars. Yet allHowever, all three options ... will have their supporters" (Lampe 1996).

Tito initially tried to establish a Yugoslav identity through strong partisan movement against the fascist occupation. After 1948, by means of anti-Stalinism, he chose "the third way", that of self-management socialism as well as brotherhood and unity. Creation of Serbo-Croatian language as an official language in the four republics (Serbia, Croatia, Bosnia and Montenegro) made it possible for more than $70 \%$ of Yugoslavs of a common official language. Establishment of consolidated state structures during the regime of Tito, through increasing welfare and a series of other measures, made it possible to replace nationalist feeling among the different republics of the former Yugoslavia. After Tito's death, the economic crisis grew, the standard of living dropped and nationalist identities began to rule. In these conditions, nationalism became a refuge for the people of the former Yugoslavia, where they found their natural protection (Fischer 2008). 
Social ties between the two republics (Montenegro and Serbia) after 1990 still remain strong and intense. Large numbers of Montenegrins still A large number of Montenegrins live and work in Serbia. They have consistently been supportive of the federation and sometimes claim that there are more Montenegrins in Serbia than in Montenegro. Such claims are impossible to verify, because If we take steps to such checks, it is impossible to verify them. This is because many individuals consider themselves to be at the same time as Serbs or Montenegrins.According to the 1991 census, there were 74,000 Montenegrins in Central Serbia, 45,000 in According to the 1991 census, there were 74,000 Montenegrins in Central Serbia, 45,000 in Vojvodina and 20,000 in Kosovo. 8Traditionally, many Montenegrins study in Serbia, Traditionally, many Montenegrins study in Serbia, especially in Belgrade. There are many family ties across the republican border, and many There are many family ties across the borders of republics. Many citizens have properties in the two republics. In general, however, the institutional and functional links between the two republics are nowHowever, institutional ties between the two republics have had their ups and downsvery limited - far less, for example, than between two member states of the European Union.. Montenegrins have created political elites and administrative structures, where among others, have their interest for the existence and continuity (PAVLOVIĆ 2003).To reconstitute a meYugoslav history shows that this is not eas

According to Pavlovic, the relationship between Serbs and Montenegrins originate deep in the history and development over the years of relations between Montenegro and Serbia, as they have common roots, the same language and the common Orthodox religion (Jessup, John E. 1989). Referring to the above elements, we find it easier to understand what unites Montenegro and Serbia, in relation to the population of the states of the former Yugoslavia. If we analyze the situation, Croats are mostly Roman Catholics and have developed a particular agenda of their language; Bosniaks are mostly Muslims; Macedonians speak other language; Slovenes have their own language different and were the first to flee from Yugoslavia; in Kosovo is spoken an entirely different language and the majority of the population belongs to the Muslim faith.

\section{Strengthening the Montenegrin Identity in the Period of the Federal Republic of Yugoslavia}

On 11 November 1945 elections were held, with the National Front on the ballot winning, securing all 354 seats. On 29 November, while still in exile, King Peter II was deposed by Yugoslavia's Constituent Assembly, and the Federal People's Republic of Yugoslavia was declared (Tito, without losing time, created the Federal Republic, which consisted of six republics. Montenegro, in the framework of historical tradition, was separated from Serbia, so as not to give weight to the Serbian influence in the bosom of the federation, although most of Montenegrins of that time considered themselves Serbs. They were encouraged to aquire the Montenegrin nationality (Bernd. J. Fischer 2008).

Timm Judah reveals a very interesting fact about Montenegro. He cites the well-known dissident Milovan Djilas to have told Tito: "Montenegrins do not want to be a separate republic, because they are the same as Serbs (both eyes of the same head)". Tito told Djilas: "If Montenegrins do not need a separate republic, I need it, for maintaining balances and domestic needs ". Tito on his own initiative decided in 1945 that the Republic of Montenegro will be part of the Yugoslav federation. This is to show the personal power and his political visionary ambitions (Judah 1997). Milovan Djilas claims in his book "The Story from Inside" (1968) that "Tito was a master of manipulation of power. He needed Montenegro precisely to preserve internal balances me qëllim mbatjen e pushtetit".

If analyzing the 1931 census, the population of Montenegro was declared Serbian Orthodox 80.88\%, so there were no differences between the Serbs and Montenegrins. In the census of 1948, the promotion of Montenegrin nationality by Tito and his associates, as well as Russian support, enabled to declare over $90.67 \%$ Montenegrin, $1.78 \%$ Serbian, $0.1 \%$ Muslim, 15.5\% Albanian, 1. 8\% Croatian. The Muslim nationality almost does not exist in Montenegro, so it is merged into a single one with the Orthodox nationality, according to the 1948 census. The reasons are that Montenegro and Serbia were undisputed triumphants of the war in former Yugoslavia of 1945.

Montenegro has been peripheral Republic after World War II as part of the Yugoslav Federation, and did not possess the same weight in inter-republican debates. This is due to the population and its small size in relation to Croatia, Serbia or other republics. The identity of the Republic of Montenegro had two "homeland" at the same time. A significant part of Montenegrins identified themselves as Serbs. A large number of Montenegrins aligned themselves on the side of Stalin, because of their historical ties and their traditional loyalty to Russia. In June 1948, the Montenegrin communists, who were brought up with the greatness of the figure of Stalin, soon found themselves marginalized and were excluded from the higher functions of the state in the Yugoslav Federation. They paid this loyalty with their removal from power.

Regarding the ethno-cultural background, Tito played an important role in preserving and strengthening the identity and Montenegrin state. If we compare the census data of 1948 with 1953, there is a decrease of Montenegrin nationality 
of $4.06 \%$ and an increase of Serb nationality of $1.52 \%$. This change is due to the break with the Soviet Union. This was reflected at the expense of Montenegrin nationality. For the first time, Yugoslav nationality appears with $1.52 \%$. The postwar generation, though acknowledged ethnicity, however, feels Yugoslav. Partisan War enabled the unification of all nationalities, so this constitutes the delicate moment of situations in 1948, when they separated from the influence of the Soviet Union (Bernd.J. Fischer 2008).

Table no. 1. "Census of Population, Households and Dwellings in Montenegro 2011" (PDF), Monstat.

\begin{tabular}{|c|c|c|c|c|c|c|c|c|}
\hline \multicolumn{3}{|c|}{ The growth of population in Montenegro } & Montenegrin & Serbian & \multirow{2}{*}{\begin{tabular}{|l|} 
Muslim \\
$14.96 \%$ \\
\end{tabular}} & \multirow{2}{*}{\begin{tabular}{|c|} 
Albaniar \\
$5.03 \%$
\end{tabular}} & \multicolumn{2}{|c|}{ Croatian Yugoslav } \\
\hline 1931 & 360,044 & $+15.6 \%$ & \multicolumn{2}{|c|}{ Serbian Orthodox. $80.88 \%$} & & & Catholi & $7.24 \%$ \\
\hline 1948 & 377,189 & $+4.8 \%$ & $90.67 \%$ & $1.78 \%$ & $0.1 \%$ & $5.15 \%$ & $1.8 \%$ & - \\
\hline 1953 & 419,873 & $+11.3 \%$ & $86.61 \%$ & $3.3 \%$ & $\ldots$ & $5.58 \%$ & $2.33 \%$ & $1.52 \%$ \\
\hline 1961 & 471,894 & $+11.3 \%$ & $81.37 \%$ & $2.99 \%$ & $6.5 \%$ & $5.47 \%$ & $2.26 \%$ & $0.33 \%$ \\
\hline 1971 & 529,604 & $+12.2 \%$ & $67.15 \%$ & $7.46 \%$ & $13.26 \%$ & $6.74 \%$ & $1.74 \%$ & $2.07 \%$ \\
\hline 1981 & 584,310 & $+10.3 \%$ & $68.54 \%$ & $3.32 \%$ & $13.36 \%$ & $6.46 \%$ & $1.81 \%$ & $5.35 \%$ \\
\hline 1991 & 615,035 & $+5.3 \%$ & $61.86 \%$ & $9.34 \%$ & $14.57 \%$ & $6.57 \%$ & $1.02 \%$ & $1.02 \%$ \\
\hline & & Muslim & Montenegrin & Serbs & Bosnian & Albanian & Rome & Croatian \\
\hline 2003 & 620.145 & $3.97 \%$ & $43.16 \%$ & $31.99 \%$ & $7.77 \%$ & $5.03 \%$ & $0.42 \%$ & $1.1 \%$ \\
\hline 2011 & 620.029 & $3.31 \%$ & $44.98 \%$ & $28.73 \%$ & $8.65 \%$ & $4.91 \%$ & $1.01 \%$ & $0.97 \%$ \\
\hline
\end{tabular}

Montenegro represents only $3 \%$ of the population of Yugoslavia and only $2 \%$ of the total product. Only $81 \%$ of the population declared themselves Montenegrins (1961 census), but about 105,000 Montenegrins live in Serbia. Personal income in Montenegro is 64, where income in Yugoslavia is estimated on the average 100. In the early 1970s, Montenegrins account for over $6 \%$ of the members of the LCY and $12 \%$ of staff in the diplomatic service, and over $15 \%$ of leaders and key personnel in the Federation level, including central administration of Yugoslavia. Nearly $10 \%$ of the senior management of the army was Montenegrin. The nationalist revival of the late 1960s and early 1970s in Yugoslavia also affected Montenegro. In Montenegro, however, it expressed itself rather as Serbian nationalism than as a distinct Montenegrin nationalism. This would find its explicit expression only considerably later, when Yugoslavia developed into a decentralised federation during the 1960s and 1970s, and Montenegro participated in the debates over the redistribution of resources within Yugoslavia together with the other lesser-developed republics which profited from the Federal Fund for the Development of the Under-developed Republics (FARDUK, 1964-1990) Montenegro's participation in these discussions and the recurring struggle over the redistribution of income necessitated an articulation and defense of a specific Montenegrin interest which in turn regularly reinforced a sense of a specific Montenegrin identity (Ashgate 2000).

If we analyze and compare the census in Montenegro in the period 1961-1971, Montenegrin nationality has declined by 14. 22\% and Serbian nationality has increased by 4, 45\%, Muslims by $6.76 \%$, Albanians by $1.27 \%$ and Yugoslav nationality by $1.74 \%$. This change of nationality is the real life in Montenegro and because liberalization of life and movement to the outside in the former Yugoslavia during these years. Tito, in the majority of cases, more strongly encouraged the concept of ethnicity in the long run than fought it (Bernd.J. Fischer 2008).

This was reflected in the response to the earthquake in 1979, which devastated parts of the Montenegrin coast, including Kotor and Budva, is a case in point. Montenegro was excluded from the inter-republican debates over compensation. The final aid package was considerably smaller than hoped for: Slovenia and Croatia had argued for more aid, while Serbia kept support to a minimum. Given that Serbia was deemed responsible for the lower than expected quantity of aid, it strengthened the more anti-Serb wing within the Montenegrin leadership. Anti-Serb policy in Montenegrin communist leadership is directly reflected in the declarations of identity in 1981 when compared with the declaration of 1971, where we notice that Montenegrin nationality has increased by $1.39 \%$, Yugoslavs by $3.28 \%$, and it is determined the decline of Serbian nationality by $4.14 \%$.

In 1987, Montenegro found itself in a severe economic crisis, with massive bankruptcy (At the time, it had only 40 000 workers, with 6000 having lost their job during the economic crisis of the late 1980s). During the economic crisis, massive job cuts threatened the employment of many workers in large enterprises in the Republic. It was against this backdrop that the mass protests took place which eventually led Montenegro to join Serbia during the disintegration of Yugoslavia. During the course of the demonstrations, Kosovo Serbs, who had been the backbone of the protests elsewhere in Yugoslavia that year, joined them. Branka Magaš has described how, in a matter of days, the demonstrations were transformed. In the beginning, the protestors demanded bread and work; by the end of the same 
day, the message of the protests had already been transformed, praising Milošević and branding the Montenegrin leadership as anti-Serb (Magas 1993). Disappointment over the lack of reform, bankrupt companies, inflation and job losses found their outlet through nationalism. The party leadership of Montenegro, could offer no convincing programme of reform to counter the nationalist protests. Thus, as one observer noted on a demonstration Belgrade - which could equally apply to Montenegro - that the protesters 'came as workers and went home as Serbs (Duretic 1994).

In Montenegro, the elections were dominated by the League of Communists which, in Montenegro, alone among the republics, did not bother to rename itself prior to the elections. The Communist Party was able to secure an overwhelming victory unmatched elsewhere in former Yugoslavia, winning over 50 per cent of the votes and two-thirds of the seats in parliament. The overwhelming victory of the League had three reasons: Firstly, the 'anti-bureaucratic revolution' in the Republic had happened less than two years prior to the elections and the Serbian nationalist movement in Montenegro, represented by the new leadership of SK CG, Momir Bulatović and Milo Đukanović, who continued to be genuinely popular within the Republic. Secondly, the Communist system, despite being discredited, was still more popular than the opposition. Thirdly, the conditions for the elections were hardly free and fair; information about the political alternatives were limited and - where available - usually aimed at discrediting the opposition. If we compare the census of 1981 with 1991, due to the dominance of Serbian policy in Montenegro, Montenegrin ethnicity we have a decline by $6.68 \%$ and an increase of the declaration of Serbian nationality by $6.02 \%$. This is the last census conducted in contemporary way in all the republics of Yugoslavia, where only $9 \%$ of the population were declared Serbian (Goati 1990).

\section{Montenegrin Identity and Influence in a Call for Independence}

A referendum in Montenegro, which took place on March 1992, confirmed Montenegro's commitment that 95.94 per cent of the electorate supported the idea of a joint state, despite the relatively low turnout of 66 per cent. Because the process of voting was boycotted by the minority and many people supported the idea of independence, I do not think that this referendum was being held in democratic conditions. Such a result made possible the extension of the federal relationship between Montenegro and Serbia for 16 years. In this period, there are two phenomena that we should analyze: one policy regarding relations with the international community, and the other with the identity in the countries. These two alternatives conditioned the emergence of new sovereign state in Europe. Economic sanctions, suspension of maritime trade and the decision of the federal authorities (Serbian) to apply the visa regime with many countries, only soured Serbo-Montenegrin relations because it prevented the arrival of visitors and tourists in Montenegro. International embargo affected Montenegro arguably more than they did Serbia, and the genuine unpopularity of the war in Bosnia, which affected Montenegro strongly as a result of the influx of Serbian (but also Bosniak) refugees from Herzegovina. The rift between Montenegro and Serbia lasted nearly two years - from late 1991, following the failed Montenegrin support for the Carrington Plan and the refusal to send soldiers to fight in Croatia, until mid-1993. (Višnjić, 1994).

Census data are important indicators regarding the amendment of national identity in Montenegro. These movements, with the changing of the structure of the identity of the population in Montenegro, were observed at the time of major changes, particularly after 1990, a time when the breakup of Yugoslavia also came, as well as with the change of policy towards Serbia in 1997. Statistics and data of 1948 show that the vast majority of people who declare themselves as Montenegrin resulted in growing resentment against Serbs, (Goati 1990). The disenchantment of the DPS with the Socialist Party in Serbia became visible when the DPS decided to form a grand coalition with the Socialdemocrats, the People's Party and the Liberal Alliance, Montenegrin nationalist party. This represented an attempt to stabilise itself after the protracted worsening of relations with the authorities in Belgrade, and given the threat posed by the Serbian Radical Party and the paramilitaries who were active in Montenegro, especially in the northern areas where lived both the Bosniak-Muslim minority and a large number of supporters of Serb nationalism (Goati 1990).

Đukanović's victory in presidential elections against Momir Bulatović, Montenegro began to distance itself from Milošević marking the rapprochement with the West. This contributed to the consolidation of the independence project, and is transmitted to the public by the main political forces led by Đukanović. Despite the fact that steps towards independence were led by political and economic reasons, they were accompanied by a new sui generis national identity, no different from the virulent nationalisms in Eastern Europe and the Balkans (Smith 1998).

This is a civic nationalism, which was functional for the constitution of a multicultural community that can identify themselves in the country, including ethnic and religious minorities. The reaction to such a program, that in favor of the union, ie mainly Orthodox Slavs, enabled Montenegrins to recognize themselves as Montenegrins, not as Serbs. This gave essentially a regional value to the identity of Montenegro, which was territorially limited to the old historical region of 
Montenegro (Bieber 2004). This excludes the mountainous northern areas of the former Sandzak in Novi Pazar, the east municipalities near the border with Albania and Kosovo, and the coast that remained under the rule of the Habsburg family until 1918. For this reason, the debate over independence is regarded as a useful instrument that can bring Montenegro closer to the rest of Europe, contributing to the creation of the concept of Montenegrin identity. It helped the famous thesis of $\mathrm{B}$. Anderson, who claimed that nations exist because they are "imagined communities" that thrive again.

EU Representative for Foreign Policy and Security, Javier Solana, reached an agreement in 2002 where each republic would commit to stay in the new federation for at least three years. Following this period, it can declare its independence, without the consent of the other republic. Immediate secession of Montenegro could cause a chain reaction in the Serb Republic of Bosnia and Kosovo. This threatened to destabilize the entire region (Huszka 2003). Therefore, in exchange for this three year delay that the EU would guarantee, the EU got the fact that Montenegro's republic renounced its independence. EU did not like at all the prospective of having an international free port with sovereign rights in the Mediterranean area, and that could have become the collector of goods coming from outside of the Community, ready to be smuggled into the Community's territory (Bieber 2002).

Census of 1991 with those of 2003, it is observed that we have a reduction of Montenegrin ethnicity by $18.7 \%$, and increase of the Serbs by $22.65 \%$, a reduction of Muslims by $10.6 \%$ and a creation of a new identity "Bosnian" by $7.77 \%$. Evolution of identities that started in 80-s and 90-s of XX century, and the fundamentally political nature of which was obvious, which was clearly reflected in the 2003 census. Slavic Orthodox population of Montenegro accounted for about $75 \%$ of the total number, where Serbian population grew by 3.4 times, whereas the Montenegrin population reduced by $22 \%$, while the Bosnians around $8 \%$. In a situation of political divisions in the republic of Slavic element, where the conflict took the dimension of antagonism between ethnicities, the highest powers political in Montenegro would not have succeeded in their goals for the cancellation of the federal relationship with Belgrade unless rely on the consent of $43 \%$ of the population, who have declared themselves as "Montenegrins". For this reason, participation in the project of Bosnians, Muslims, Albanians, Catholics and Croatian minorities, became a necessity. Therefore, the hypothesis of a multicultural state had been born. This would be a model country in Western Europe, where every citizen could identify himself in this country, regardless of his native language, religion or culture. As above, it is interesting to be noted how the case of Montenegro is very different from the model of the Slovenian, Macedonian or Croatian nation state.

\section{The Phenomenon of Identity Shifting and Declaration of Independence in Montenegro}

Border regions in Montenegro are, effectively, the pages of identity shifting, in which we have a large population of Bosnian Muslims. Croats are located in the north of Montenegro, while Serbs in the south-west, Albanians in south-east and both have Muslim and Albanian population. These populations constitute the relevant nationality elements in terms of Project Independence. These regions have always promoted the image of the quiet and welcoming regions although with diversity of faith and different cultures. Their vote was crucial to the declaration of independence of Montenegro (Berg 1999).

In order to understand and examine the phenomenon of identity shifting in Montenegro, this thesis focuses on the theoretical treatment of the border regions and in the issue of self-declaration of the people who constitute these regions. Attention is paid to population in the north, south-west and south-east of the country, as the study shows that a number of people have changed their identity declaration. So here we have the phenomenon of concealment and identity shifting (Dzankic 2012). These were mostly reflected in the northern part of the country, where a large number of Muslims originate from the Sandžak region, as well as in the city of Bar known for its high tolerance and peaceful cohabitation of Catholics, Orthodox and Muslims. It is precisely in these regions that a noticeable switch from Muslims to Bosniaks (Bošnjaci) in the census records occurred. Matica Muslimanska of Montenegro is an organisation that is promoting an identity that claims Montenegrin nationality but Islam as religion, while the Bosniak Council opts for a Bosniak identity which includes Bosniak nationality and Islam as religion (Bieber 2014). This fragmentation of society, just as in the Montenegrin case represents an anomaly in institutional nationalism, as the 'titular nation' does not represent more than $50 \%$ of the overall population.

The result of the referendum stirred and provoked ethnic tensions. This is a reality, particularly in the multi- ethnic northern part of the country, where according to the scholar Sead Sadikovic it is estimated that: in $2006,45 \%$ of the population were Serbs, 38\% Bosniaks (Muslims) and 20\% Montenegrin (Sadikovic 2006). In this part of the country, the majority of Serbs is in favor and supports the Union, but Bosnians and Albanians support independence, whereas Montenegrins were between. For Bosnian Muslims, identity comes from Muslim religion, while the Serbian part of Sandzak is something secondary. 
However, what makes the case of Montenegro a paradox and perhaps unique in the world, is the fact that there were no inter-ethnic contrasts between nationalities, as has happened in other former republics of Yugoslavia, but intraethnic contrasts (Kaspersen 2003), with an internal division between Slavic Orthodox people who make up more than $70 \%$ of the population. This reveals its political origin of the conflict on the fact that those who are in favor of EU identify themselves as Serbs and those who are in favor of independence identify themselves as Montenegrins. In such groups, identity is a personal choice, and the "ethnic" division may also occur within the family. Djukanovic, as the architect of independence and development and achievements of Montenegro, in a speech at the congress of DPS (October 2001) stated that full sovereignty of Montenegro would have been a punishment for the disappearance of the state and the nation. He also considers that what primarily matters is the preservation of the state, and not the identity of Montenegro as a nation. Djukanovic's goals can be assessed and this is confirmed by the events that have occurred over the years, and this the results show that he did not want to create an ethnically based state, taking into account the unclear nature of the Montenegrin identity (Dimitrovova 2003).

Regions of "identity shift" which were borded by Albania and Kosovo, which are mainly inhabited by Bosnian Muslims and Albanians, were in favor of independence (78.92\% in Plav, $91.33 \%$ in Rozaje). Herceg Novi, with a majority of Serb population voted against independence with $60.75 \%$. Southern regions as (Tivat, Kotor, Budva and Bar) have voted in favor of independence. Municipality of Ulcinj which is at the center of ethnic Albanians voted in favor of independence (88.64\%). A crucial and decisive role in the independence of Montenegro was the vote of the Albanians and Bosnians (BU, 2007).

\section{Identiteti dhe Ndërtimi i Shetit në Mal të Zi}

Censuses in Montenegro held in 2011, which were the first censuses in this new and independent state, proved again that Montenegro is a multinational state. None of the people who live in this country, does not have the absolute majority including its constituent people, ie the Montenegrin people, who constitute $45 \%$ of the total population in Montenegro. In fact, the so-called minorities together make up $55 \%$ of the population, ie minorities make up the majority in this country. In this context, the categorization of peoples into "majority" and "minority" in Montenegro loses its meaning and as such it has only a relative connotation. So, Montenegrins are the majority only in comparison with other nations. Montenegro is one of the only countries that emerged from the breakup of the former Yugoslavia, where the percentage of constituent people (ie Montenegrins) represents less than $50 \%$ of the total population. Furthermore, in terms of the demographic diversity, Montenegro is one of the rare countries in the region. It is evident that the Constitution of Montenegro does not reflect the reality of its national structure, but favors only the Montenegrin people. The bitter history teaches us that in multiethnic states, if a nation claim to dominate the other nations, are doomed to fail. The case of the Federation of Yugoslavia, where the Serbian people aspired to dominate over other people, is the best example of how can a multinational state end, if all the nations that are in its state composition are not treated in the same way or do not have all equal status.

Three major ethnic groups in Montenegro are Serbs (28.7\%), Bosniaks (8.6\%) and Albanians (4.9\%). Various factors, such as migration, refugee placement, and changes in ethnic identification, have changed the ethnic and demographic structure of Montenegro during the breakup of Yugoslavia and subsequent wars in the 1990s (Bieber 2003). Given the historical past and their high rates, there has been debate on whether Serbs should even be considered as a minority in this country. Montenegrins and Serbs, were members of the same nation for more than 85 years. Consequently, self-identification as Serbs or Montenegrins in the Montenegro for many years has been an issue of personal choice, based on political, cultural and other aspects. Such an "ethnic" division actually existed even within many families in the country. However, the Serbs of today have been officially considered as a minority in Montenegro and in principle is distributed throughout the territory of the countryt. According to the 2011 census, the Serbs have absolute majority in three municipalities, and are relative majority in three other municipalities. These represent less than $20 \%$ of the population in only four municipalities of the total 23 municipalities in the country. Throughout history, generally seen, Montenegrins have had long periods of coexistence, and even periods of identification with Serbs (Hastings 1997). Therefore, many scholars have argued that Montenegrins are basically part of the Serbian nation, which is located in this region after their losses in different wars (Watson 1996). However, there are many others who believe that Montenegrins are a separate nation, with a different political history and a long-term existence of a horizontal visible self-identification. What is true, however, is the fact that, for centuries, there has been no ethnic conflic between Montenegrins and Serbs. 


\section{Conclusions}

Yugoslavia was based on the recognition of different nationalities, where the protection of their collective rights was more important than the protection of their individual and civil rights.

Montenegro's interest has been the preservation of nationalism among citizens, which was functional for the constitution of a multicultural community that can identify itself in the country, and where ethnic and religious minorities are included. It must accept a "state of its citizens" regardless of what nation they belong. All citizens are equal before the law. Minorities still have political demands regarding the quotas for their representation in parliament, in the institutions as well as in the public administration. Their representation requires expression by a special law by parliament in order to be part of a society that does not reject the state and the nation. Montenegro's case is very different from the model of other nation-state of Yugoslavia. The difference consists on the multicultural state. Montenegro should assess the contribution of minorities and many ethnic groups in the country, as an irreplaceable asset in achieving the independence and development of the country. Respect for many ethnicities is a cornerstone and a guarantee for EU integration.

\section{References}

Srđa Pavlović, Ballkan Anschluss: Annexation of Montenegro and establish joint Yugoslav state (Purdue University Press, 2008)

John R. Lampe, History of Yugoslavia (Cambridge and New York, Cambridge University Press, 1996), p. 98.

Bernd J. Fischer Balkan dictators, Tirana 2008, p. 325- 485

Statistical Office of Montenegro Census 1991, (PDF), Monstat.

Pavlović Srđa, "Who are Montenegrins?" Statehood, identity, and civic society, in BIEBER F. (ed.), Baden-Baden, 2003, pp. 83-106.

Jessup, John E. (1989). A Chronology of Conflict and Resolution, 1945-1985. New York: Greenwood Press. ISBN 0-313-24308-5.

Bernd J. Fischer, Balkan dictators, Tirana 2008, fp307

Timm Judah. The Serbs. Myth and History (New Haven and London: Yale University Press, 1997) p. 158-169. Sipas tabelës 1. Montenegrin Census' from 1909 to 2003.

On the issue of Montenegrin identity, see Srđa Pavlović: "Who are Montenegrins?" this volume. Sipas tabelës 1. Montenegrin Census' from 1909 to 2003.

Bernd J. Fischer, Balkan dictators, Tirana 2008, p 342 http://web.archive.org/web/20121110192905/http://www.foia.cia.gov/CPE/ESAU/ esau-46.pdf

Sabrina Petra Ramet: Nationalism and Federalism in Yugoslavia. 1962-1991, 2nd Ed. (Bloomington, In.: Indiana University Press, 1992), p. 116.

Ramet: Nationalism and Federalism, pp. 150-158.

John B. Allcock: 'Montenegro', in David Turnock and Francis W. Carter (eds.): The States of Eastern Europe. South-Eastern Europe, Vol. 2 (Aldershot: Ashgate, 2000), p. 185. Sipas tabelës 1. Montenegrin Census' from 1909 to 2003.

Bernd J. Fischer, Balkan dictators, Tirana 2008, p 344.

Ramet: Nationalism and Federalism, p. 160. Sipas tabelës 1. Montenegrin Census' from 1909 to 2003.

Branka Magaš: The Destruction of Yugoslavia, Tracking the Break-Up, 1980-92 (Verso: London/New York, 1993), pp. 170-171.

Jagoš Đuretić, quoted from Slavoljub Đukić: Između slave i anateme. Politička biografija Slobodana Miloševića (Beograd: Filip Višnjić, 1994), p. 106. Ivan Čolović describes this transformation on the basis of the slogans used by the demonstrators. Čolović: Bordell der Krieger, pp. 138-142.

Vladimir Goati: Izbori u SRJ od 1990 do 1998: volja građana ili izborna manipulacija (Beograd: CeSID, 1999), p. 36. Table 1. Montenegrin Census' from 1909 to 2003

See Lenard J. Cohen: Broken Bonds. The Disintegration of Yugoslavia (Boulder, Co: Ëestvieë, 1993), pp. 158-159. Fesbook CIA data of 1990, p 27-33.

Goati: Izbori u SRJ, pp. 34-40. web.ceu.hu/crc/Syllabi/alumni/polsci/careja.html (see Smith, 1998, pp. 291-300, Concepts such as citizenship, ethnicity, identity, national identity, nationalism and ... Oxford: Clarendon Press. 1998).

Florian Bieber, 2004, pg. 84 http://www.policy.hu/bieber/Publications/2005 FH Serbia.pdf, Huszka, 2003, p. 43. https://www.surrey.ac. uk/cronem/files/.../violante.doc Antonio Violante

Bieber Florian, The Instrumentalization of Minorities in the Montenegrin Dispute over Indipendence, European Centre for Minority Issues (ECMI) Brief \# 8, March 2002, p. 6), available online. www.ecmi.de.

Republic of Montenegro, Statistical Office, Podgorica, 2006.

David I. Kertzer dhe Dominique Arel (Cambridge University Press, 2002), 2Hastings Donnan dhe Thomas M. Ë ilson, Kufij: Frontiers e identitetit, Kombit dhe shtetet (Berg, 1999).

Jelena Džankić, "Minorities in the Tangles of Citizenship, Participation, and Access to Rights" Journal on Ethnopolitics and Minority Issues in Europe"11, no. 3 (July 2012): 46.

Erin K. Jenne dhe Florian Bieber, " Nationalism situation: Nation-Building në Ballkan, Institucionet subversive dhe Paradox Malit të Zi, " Ethnopolitics: Formerly Global Review of Ethnopolitics 13, no. 5 (2014): 431 - 460

It can be seen hoë, considering the declared percentage; the presented data does not represent the situation ëith arithmetic precision, 
but is only an indicator. Sadiković, 2006.

Caspersen, 2003, passim p. 117.

Šístek, Dimitrovová, 2003, p. 159.

Balkan Update: Albanian and Bosniacs make Montenegro independent Archived September 28, 2007, at the Wayback Machine.

Šístek, František and Dimitrovová, Bohdana, "National minorities in Montenegro after the break-up of Yugoslavia," në Montenegro in Transition: Problems of Identity and Statehood, Florian Bieber (red.), Nomos Verlagsgesellschaft, BadenBaden, 2003, pg. 159. Population Census in Montenegro 2011

Pavlović, Srđa, "Who are Montenegrins? Statehood, identity, and civic society," in Montenegro in Transition: Problems of Identity and Statehood, Florian Bieber (red.), Nomos Verlagsgesellschaft, Baden-Baden, 2003, p. 83-107.

"Structure of Population by Ethnicity for Municipalities in \% Population Census in Montenegro 2011, Statistical Office of Montenegro, http: //www. monstat.org/eng/page57php?id=393\&pid, 30. 10. 2014.

Hastings, Adrian, The Construction of Nationhood: Ethnicity, Religion and Nationalism, Cambridge: Cambridge University Press, 1997, p. 142.

Watson, R. W. Seton, The Rise of Nationality in the Balkans, New York: Howard Fertig, 1966, p. 31. 